\title{
Comparative physiological and biochemical mechanisms of salt tolerance in five contrasting highland quinoa cultivars
}

\author{
Zhi-Quan Cai ${ }^{1,2^{*}}$ and Qi Gao ${ }^{2^{*}}$
}

\begin{abstract}
Background: Chenopodium quinoa Willd., a halophytic crop, shows great variability among different genotypes in response to salt. To investigate the salinity tolerance mechanisms, five contrasting quinoa cultivars belonging to highland ecotype were compared for their seed germination (under 0, 100 and $400 \mathrm{mM} \mathrm{NaCl}$ ) and seedling's responses under five salinity levels $(0,100,200,300$ and $400 \mathrm{mM} \mathrm{NaCl})$.

Results: Substantial variations were found in plant size (biomass) and overall salinity tolerance (plant biomass in salt treatment as \% of control) among the different quinoa cultivars. Plant salinity tolerance was negatively associated with plant size, especially at lower salinity levels $(<300 \mathrm{mM} \mathrm{NaCl})$, but salt tolerance between seed germination and seedling growth was not closely correlated. Except for shoot/root ratio, all measured plant traits responded to salt in a genotype-specific way. Salt stress resulted in decreased plant height, leaf area, root length, and root/shoot ratio in each cultivar. With increasing salinity levels, leaf superoxide dismutase (SOD) activity and lipid peroxidation generally increased, but catalase (CAT) and peroxidase (POD) activities showed non-linear patterns. Organic solutes (soluble sugar, proline and protein) accumulated in leaves, whereas inorganic ion $\left(\mathrm{Na}^{+}\right.$and $\left.\mathrm{K}^{+}\right)$increased but $\mathrm{K}^{+}$/ $\mathrm{Na}^{+}$decreased in both leaves and roots. Across different salinity levels and cultivars, without close relationships with antioxidant enzyme activities (SOD, POD, or CAT), salinity tolerance was significantly negatively correlated with organic solute and malondialdehyde contents in leaves and inorganic ion contents in leaves or roots (except for root $\mathrm{K}^{+}$content), but positively correlated with $\mathrm{K}^{+} / \mathrm{Na}^{+}$ratio in leaves or roots.

Conclusion: Our results indicate that leaf osmoregulation, $\mathrm{K}^{+}$retention, $\mathrm{Na}^{+}$exclusion, and ion homeostasis are the main physiological mechanisms conferring salinity tolerance of these cultivars, rather than the regulations of leaf antioxidative ability. As an index of salinity tolerance, $\mathrm{K}^{+} / \mathrm{Na}^{+}$ratio in leaves or roots can be used for the selective breeding of highland quinoa cultivars.
\end{abstract}

Keywords: Chenopodium quinoa, Salt stress, Antioxidant enzyme, Growth, Inorganic ions, Organic solutes

\section{Background}

As a global issue, soil salinisation limits agricultural production because of its detrimental effect on seed germination, plant growth and crop yield [1,2]. In order to tolerate soil salinization conditions, besides anatomical and morphological plasticity, plants have evolved multiple physiological mechanisms, e.g., osmotic adjustment, increased antioxidant response, accumulation or exclusion

\footnotetext{
* Correspondence: zhiquan.cai@126.com; gaoqi@xtbg.org.cn

'Department of Horticulture, Foshan University, Foshan 528000, China

${ }^{2}$ CAS Key Laboratory of Tropical Plant Resources and Sustainable Use, Xishuangbanna Tropical Botanical Garden, Chinese Academy of Sciences, Mengla 666303, China
}

of ions, and ion homeostasis to maintain plant growth. For osmotic adjustment, inorganic ions $\left(\mathrm{K}^{+}, \mathrm{Na}^{+}\right.$and $\left.\mathrm{Cl}^{-}\right)$ and compatible organic solutes (e.g. soluble sugars, proline, glycine betaine, and polyamines) are the key osmolytes which play vital role to reduce cell water potential $[1,3]$. However, the contribution to osmotic adjustment via accumulation of organic solutes under salt stress is still disputed, depending on the species/genotypes, duration and intensity of the stress, confounding effect of other factors, and also leaf and/or plant ages $[4,5]$.

Being a physiologically and genetically complex trait, salinity tolerance is associated with multiple subtraits (e.g. osmotic balance, ion homeostasis, and reactive 
oxygen species regulation), each having a complex and less understandable genetic basis [1]. Thus, genetic variation can be testified indirectly by measuring the responses of different species and/or genotypes, as well as by ontogenetic stages. As salt tolerant plants are rare $(<0.25 \%$ of flowering plants [6];) and the majority of main crops (rice, maize, etc.) belong to glycophytes, for growers, the most efficient way is the usage of alternate salt-adaptive crop species (obligatory halophytes), minimizing the harmful effects of salinity on crop's growth and production.

Quinoa (Chenopodium quinoa Willd.) belonging to the family Amaranthaceae, a pseudo-cereal native to Andes, has provided nutrition and medicine for the local people over several thousands of years, owing to the high content of health-beneficial phytochemicals in seed [7]. Resistant to multiple abiotic stresses (e.g. drought, salinity, frost and poor soils), quinoa offers to be a promising crop to endure the increasing drought and salinity conditions under the global climatic change scenario [8]. Being cultivated in widely edapho-climatic conditions since about last 7000 years, the broad diversity has traditionally led to the classification of five quinoa ecotypes adapted to different native geographic environments: salares, highlands, inter-Andean valleys, yungas, and coastal lowlands [9]. Among them, although it is well-known that salares landraces have the highest salinity tolerance, extent of salinity tolerance of the highland ecotype, growing at high altitudes around Titicaca Lake, has received less attention. Serving as a putative model halophytic crop, quinoa displayed a wide degree of variability in salinity tolerance strategies based on its genome $[10,11]$. Apart from the distinct anatomical features, i.e., salt bladders on both leaf adaxial and abaxial surfaces, salinity tolerance in quinoa plants was achieved through multiple strategies operating simultaneously, depending on the genetic background (ecotypes or genotypes) and the duration and intensity of the stress [12-14]. For instance, plant salt tolerant and ion homeostasis are maintained by membrane transporters, i.e., SOS1 (salt overly sensitive), $\mathrm{NHX} 1\left(\mathrm{Na}^{+} / \mathrm{H}^{+}\right.$exchanger), $\mathrm{H}^{+}$-ATPase, HAK (high-affinity $\mathrm{K}^{+}$transporter) and HKT (high-affinity $\mathrm{K}^{+}$transporter) [1]. SOS1 controls the extrusion of $\mathrm{Na}^{+}$and is also involved in the transport processes implicated in the xylem and phloem loading/ unloading of $\mathrm{Na}^{+}$in plants (long-distance transport) [1]. NHX-type antiporters in the tonoplast, mediating the compartmentation of $\mathrm{Na}^{+}$in vacuoles, have a central role in establishing ion homeostasis and have been reported to increase the salt tolerance of various plants species $[1,4$, 11]. Differential spatial and temporal expressions of these transporter genes synergistically regulate ion homeostasis by controlling $\mathrm{Na}^{+}$transport systems at the tissue- and whole-plant levels under salt conditions. In four lowland genotypes of quinoa, the expression of two sodium transporter genes (i.e. CqSOS1 and CqNHX1) was differentially induced at different tissues (shoots vs. roots), and between genotypes (more salt-tolerant vs. less salt-tolerant genotypes) [13], suggesting that plant salt tolerance may depend upon different mechanisms of ion ( $\mathrm{Na}$ and/or $\mathrm{K}$ ) uptake/exclusion, translocation and compartmentation.

On the other hand, plants resource allocation between growth and stress tolerance is a major evolutionary constrain on plants. A basic tenet of plant ecophysiology is the growth-stress tolerance tradeoff proposed by the competitor - stress tolerator - ruderal (C-S-R) triangle theory, i.e., inverse relationships between the capacity of species/genotypes to grow when resources are abundant and its capacity to tolerate resource shortage $[15,16]$. For instance, the morphological and physiological traits associated with low-light compensation points enable slow-growing species to survive well in deep shade, but lead them to be outcompeted by fast-growing species in high light [17], even irrespective of soil fertility [18]. Thus, the trade-off between plant's survival in low light and growth in high light occurred. Among tree species with a wide range of morphology and growth potential, slow-growing species having a conservative resource-use strategy are least sensitive to drought [19], although the trade-off between drought tolerance and plant growth is not always significant [20]. Moreover, the C-S-R theory does not similarly employ to all abiotic stresses [21]. A trade-off between plant growth rate and cold hardiness, but not for drought, occurred among plants in 56 families of Douglas-fir [22]. As for salinity, it was hypothesized that the osmotic effect mostly limited the growth of salt-stressed plants, irrespective of the plant's capacity of excluding salt, resulting in decreased growth rate (biomass) [2]. However, the plant growth potential and salt tolerance trade-off hypothesis was rarely tested.

Among different growth stages (e.g., establishment, flowering and seed filling) in quinoa plants, seedlings are more sensitive to salinity than mature plants [23]. Using five contrasting quinoa cultivars belonging to highland ecotype, we attempted to: (1) ascertain the intraspecific variability (different cultivars) at the establishment stages, based on the morphological (germination, growth) and physio-biochemical responses to salinity, (2) unravel how the underlying morph-physiological determinants vary at the tissue and whole-plant levels in response to salt stress, and, (3) test what the extent of the growth - salt tolerance trade-off existed.

\section{Results}

\section{Seed germination}

Compared with the control, seed germination did not significantly reduce for each quinoa cultivar in the low salt condition $(100 \mathrm{mM} \mathrm{NaCl})$. Whereas, in the high salt 
condition $(400 \mathrm{mM} \mathrm{NaCl})$, germination rates decreased for all cultivars (Fig. 1); sharp inhibition was found in 2 cultivars, i.e., cultivar BR2 and W23.

\section{Morphological and growth traits}

All plants survived throughout the experimental period (i.e., 100\% survival rate), even in the highest salt condition (i.e. $400 \mathrm{mM} \mathrm{NaCl}$ ). With the lowest value in cultivar BR2 among 5 cultivars, plant water content did not vary greatly in response to salt. Plant height, leaf area, root length, shoot and root biomass, root/shoot ratio and plant biomass generally decreased with increasing salt levels (Fig. 2a-h). Across different salt levels, plant size (biomass) among quinoa cultivars increased in the order of $\mathrm{B} 2<\mathrm{R} 1<\mathrm{BR} 2<\mathrm{W} 23<\mathrm{Y} 2$; the same pattern occurred even at the control conditions (no salt). Among them, cultivar Y2 had the largest leaf area, root length and biomass (shoot, root and total biomass), but had the medium plant height and the lowest root/shoot ratio; whereas cultivar B2 had the lowest plant height, root length and shoot and root biomass, but had the medium leaf area and the highest root/shoot ratio. Across different salt contents and cultivars, plant biomass was significant (all $P<0.05$ ) positively correlated to plant height $(r=0.49)$, leaf area $(r=0.53)$, and root length $(r=0.93)$, but not plant water content $(\mathrm{r}=0.098, P>0.05)$ and root/shoot ratio $(\mathrm{r}=0.01, P>0.05)$.

Except for root/shoot ratio, significant salt $\times$ cultivar interactions were found for the measured morphological

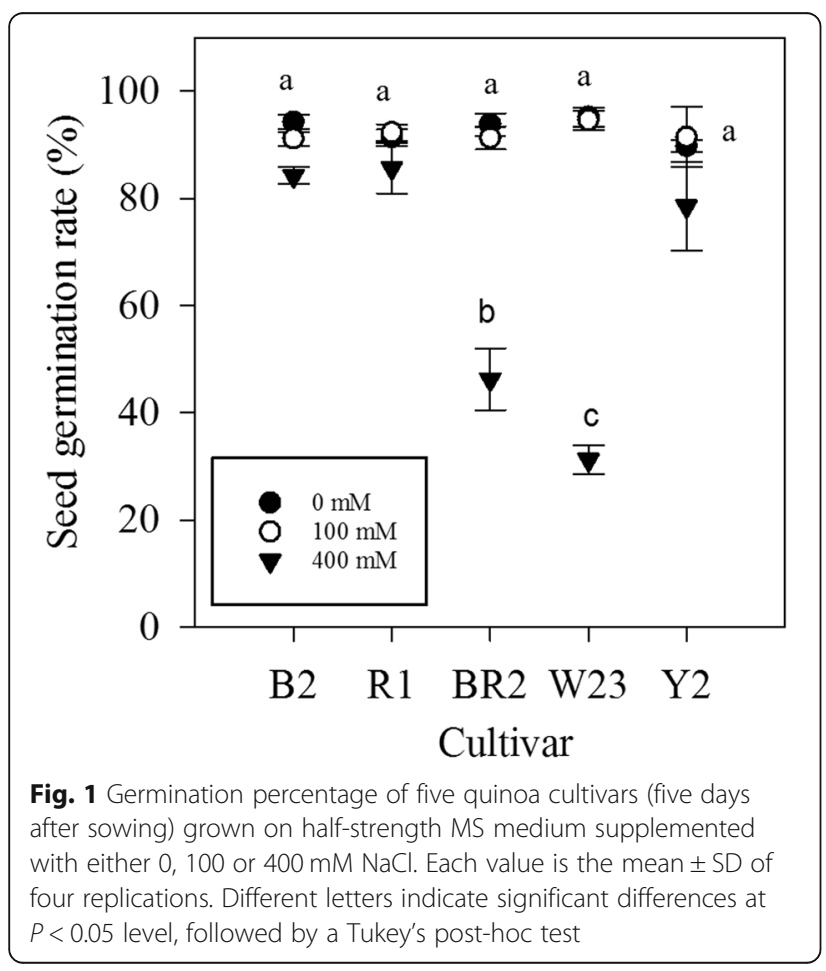

and growth traits (Fig. 2), indicating that different cultivars varied in the magnitude of their responses to salt. At lower salt levels $(<200 \mathrm{mM} \mathrm{NaCl})$, plant height significantly decreased in cultivars with relatively smaller size (i.e. cultivar B2 and R1), but did not change in cultivars with bigger size (i.e. cultivar BR2, W23 and Y2). Whereas, plant biomass did not change significantly in response to the lowest salt condition (i.e. $100 \mathrm{mM} \mathrm{NaCl}$ ) for each cultivar, but decreased sharply at higher salt levels ( $\geq 200 \mathrm{mM} \mathrm{NaCl}$ ).

Relative to the control, ranging from 38.9 to $64.4 \%$ among different cultivars, the magnitude of decrease in plant biomass at the highest salt level $(400 \mathrm{mM} \mathrm{NaCl})$ generally followed similar pattern as plant size: the decreased percentages in the bigger cultivars (i.e. cultivar W23 and Y2) were more than those in the smaller ones (i.e. cultivar B2 and R1). This was further proved by the negative correlations between plant biomass and overall salinity tolerance (plant biomass in salt treatment as \% of control) within each salt level, especially with strong relationship existing at lower salinity levels $(<300 \mathrm{mM}$ $\mathrm{NaCl}, P<0.05$ ) (Fig. 3).

\section{Antioxidant enzyme activities and lipid peroxidation in leaves}

Significant effects of salt, cultivar and salt $\times$ cultivar interactions were found for the antioxidant enzyme activities (SOD, POD and CAT) and MDA content in quinoa leaves (Fig. 4). Compared with the control, the activities of each antioxidant enzyme increased, but MDA did not accumulate greatly at the lowest salt level (i.e. $100 \mathrm{mM} \mathrm{NaCl}$ ). However, with increasing salt levels, SOD activity and MDA content generally increased (Fig. 4a, d), but POD and CAT activities showed nonlinear patterns where they first increased but decreased afterwards (Fig. 4b, c). Across different salt levels, POD activities among 5 quinoa cultivars followed similar pattern as plant size, i.e., the bigger cultivars had higher POD activities. But the cultivar with largest size had the highest MDA content, rather than SOD and CAT activities.

\section{Soluble protein, proline, sugar, and chlorophyll content in leaves}

Generally, soluble sugar, protein and proline contents increased with increasing salt levels in each cultivar (Fig. 5a-c), but the cultivars differed in the magnitude of responses to salt (significant salt $\times$ cultivar interactions, all $P<0.001)$. The significant salt $\times$ cultivar interactions for $\mathrm{Chl}$ a, Chl b and total Chl contents (Fig. 5d-f) mainly implied that the cultivars differed in their directions of the responses to salt. For example, with increasing salt levels, Chl a, Chl b, and total Chl contents were generally increased in the smallest one (cultivar B2), but decreased in other bigger ones. Across different salt levels, 

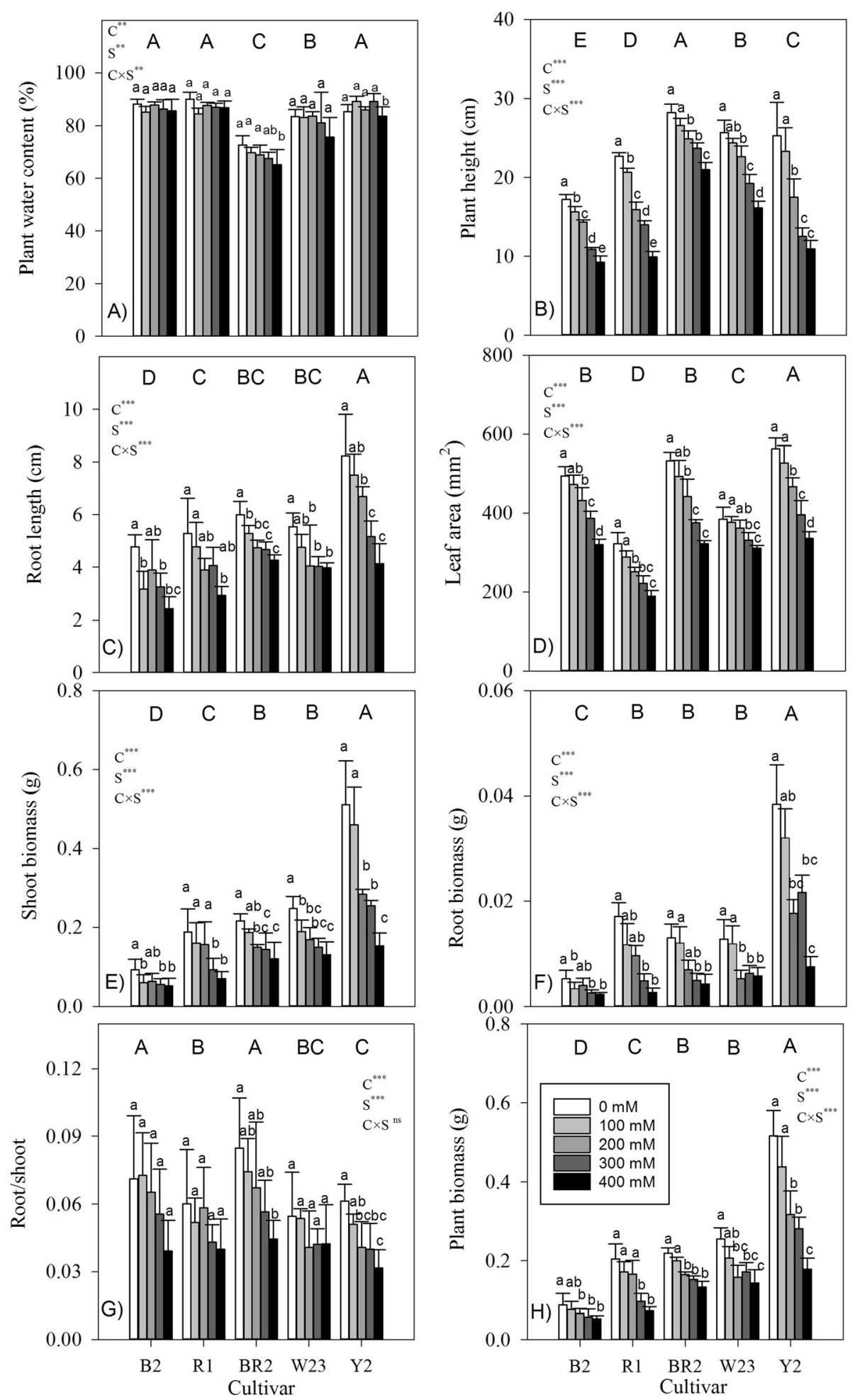

Fig. 2 Morphology and growth traits in seedlings of five quinoa cultivars under different salt levels. Different small and capital letters indicate significant differences between the saline levels $(\mathrm{S})$ within each cultivar and between cultivars $(\mathrm{C})$ across different saline levels, respectively, at $P<0.05$ level. Each value is the mean \pm SD of five to six replicate measurements. ns, not significant at $P>0.05,{ }^{*} P<0.05$, ${ }^{* *} P<0.01$, ${ }^{* * *} P<0.001$ 


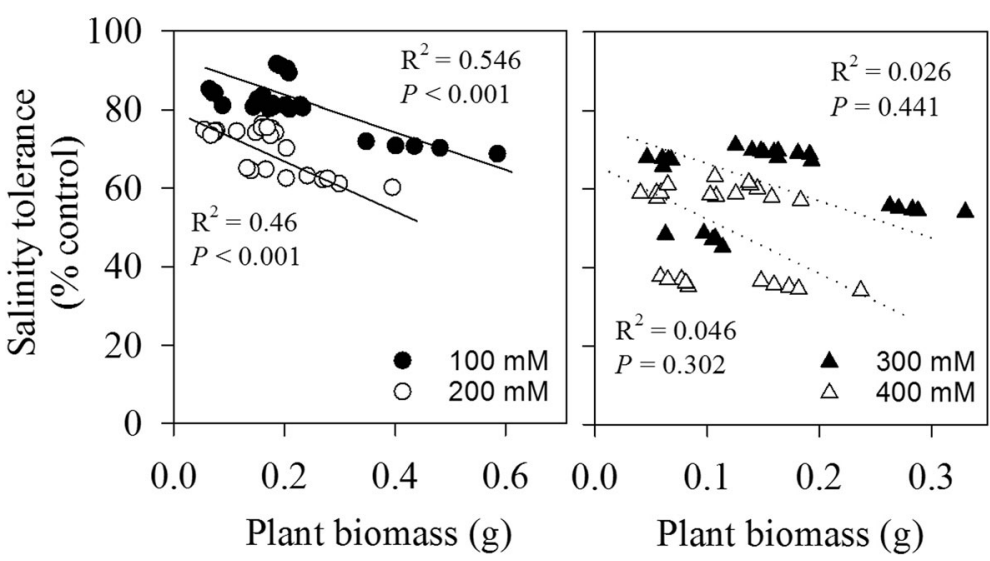

Fig. 3 Relationships between plant biomass and salinity tolerance (biomass in salt treatment as \% of control) of five quinoa cultivars in each saline level

the values of soluble, protein, proline and Chl content did not tightly follow the pattern of plant size. But plant biomass was negatively correlated to each of these organic compounds, although a significant effect was only found in proline $(r=-0.529, P<0.05)$, across different salt contents and cultivars.
$\mathrm{Na}^{+}$and $\mathrm{K}^{+}$contents and $\mathrm{K}^{+} / \mathrm{Na}^{+}$ratios in leaves and roots Compared with leaves, roots had much lower values of $\mathrm{K}^{+}$content and $\mathrm{K}^{+} / \mathrm{Na}^{+}$ratio, but had higher $\mathrm{Na}^{+}$content (Fig. 6, all $P<0.001$ ). Thus, regardless of genotype, $\mathrm{Na}^{+}$preferentially accumulated in roots rather than in leaves, and the converse was true for $\mathrm{K}^{+}$. Generally, $\mathrm{K}^{+}$
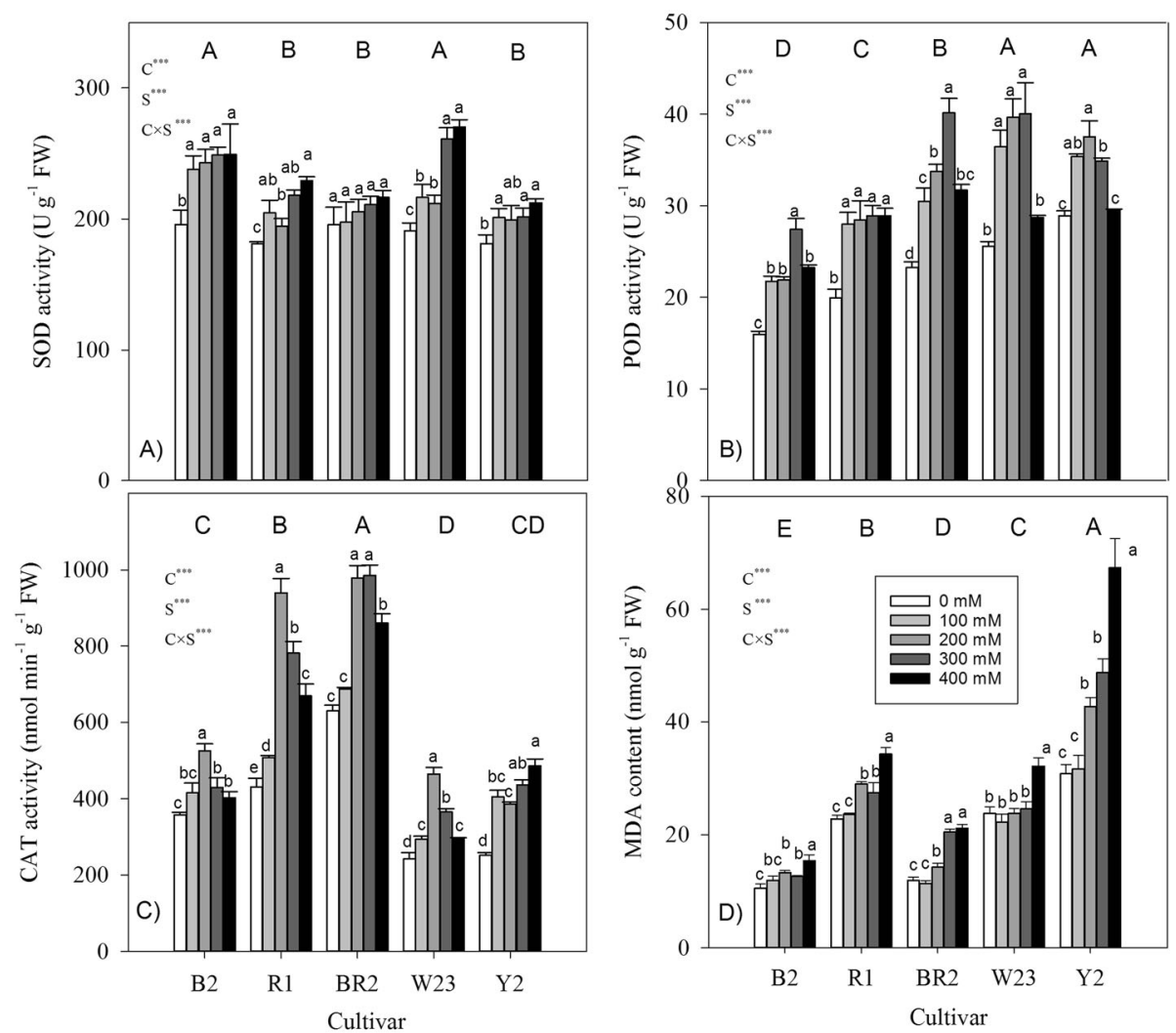

Fig. 4 Activities of anti-oxidative enzymes and chlorophyll content in leaves of seedlings of five quinoa cultivars under different saline levels. Different small and capital letters indicate significant differences between the saline levels (S) within each cultivar and between cultivars (C) across different saline levels, respectively, at $P<0.05$ level. Each value is the mean \pm SD of three to four replicate measurements. ${ }^{* *} P<0.001$ 

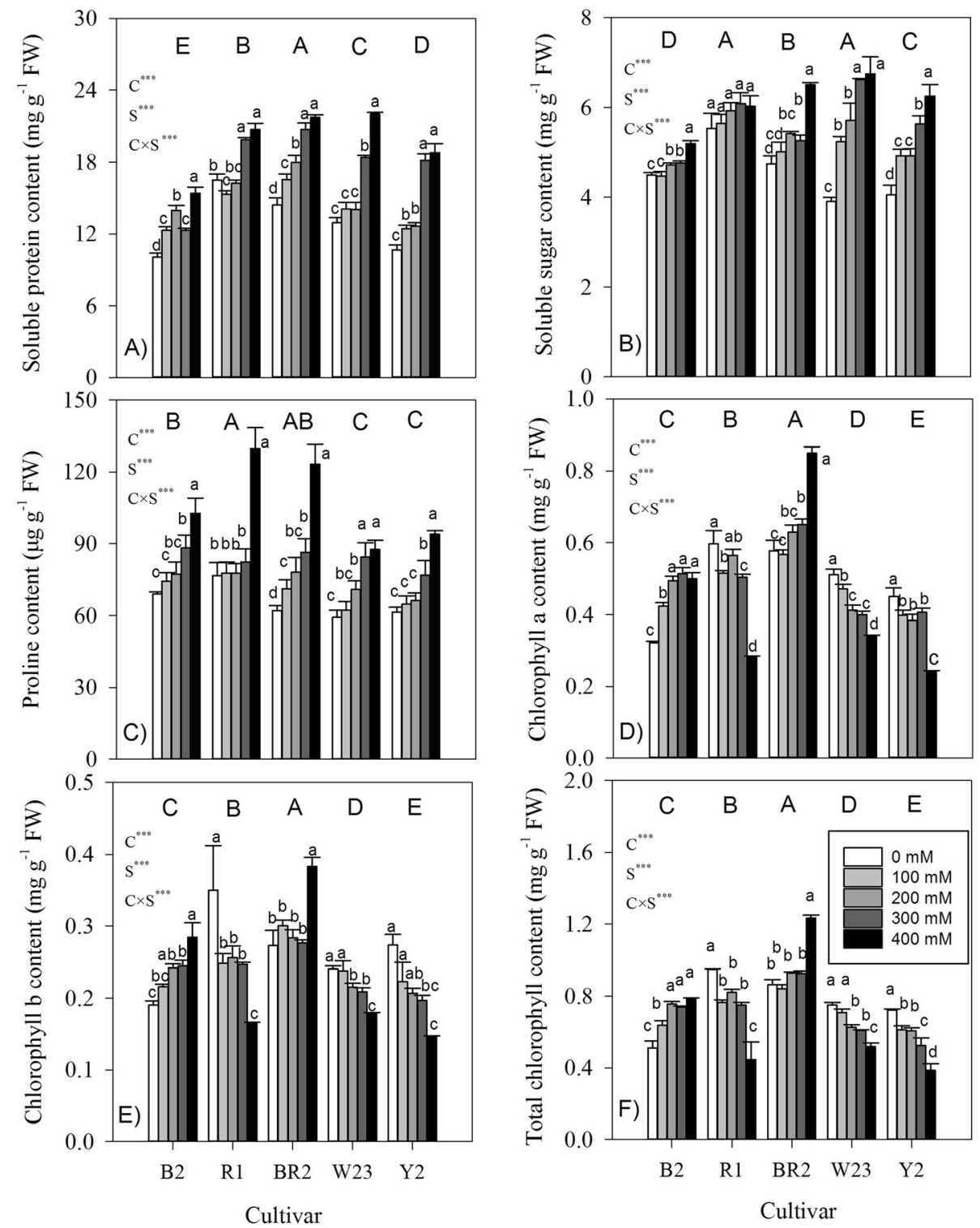

Fig. 5 Organic substances and chlorophyll content in leaves of seedlings of five quinoa cultivars under different salt levels. Different small and capital letters indicate significant differences between the saline levels $(S)$ within each cultivar and between cultivars $(C)$ across different saline levels, respectively, at $P<0.05$ level. Each value is the mean \pm SD of three to four replicate measurements. ${ }^{* *} P<0.001$

and $\mathrm{Na}^{+}$contents in both leaves and roots increased with increasing salt levels in each cultivar (Fig. 6a-d), but $\mathrm{K}^{+} / \mathrm{Na}^{+}$ratio decreased sharply (Fig 6e, f). Leaf $\mathrm{Na}^{+}$content showed a much greater variation (3.21-fold on average) at the highest salt level relative to the control, compared with that in root (1.65-fold on average). The reverse occurred for $\mathrm{K}^{+}$contents (on average 1.22 vs. 1.73-fold for leaf and root, respectively). Among cultivars across different salt levels, cultivar Y2 had the highest $\mathrm{Na}^{+}$contents and lowest $\mathrm{K}^{+} / \mathrm{Na}^{+}$ratio in both leaves and roots. But the values of $\mathrm{K}^{+}$and $\mathrm{Na}^{+}$contents and $\mathrm{K}^{+} / \mathrm{Na}^{+}$ratio in leaves or roots did not tightly follow the pattern of plant size. There were negative trends between plant biomass, and, $\mathrm{K}^{+}$and $\mathrm{Na}^{+}$contents in both leaves and roots across different salt contents and cultivars $(\mathrm{r}=-0.074--0.0421$, all $P>0.05)$, although not significantly.

\section{Relationships between salinity tolerance with variables}

Across different cultivars and salt levels, without close relationships with plant water content, root/shoot ratio and antioxidant enzyme activities (SOD, POD, or CAT), salinity tolerance was significant negatively correlated with leaf proline, protein, sugar and MDA contents, 

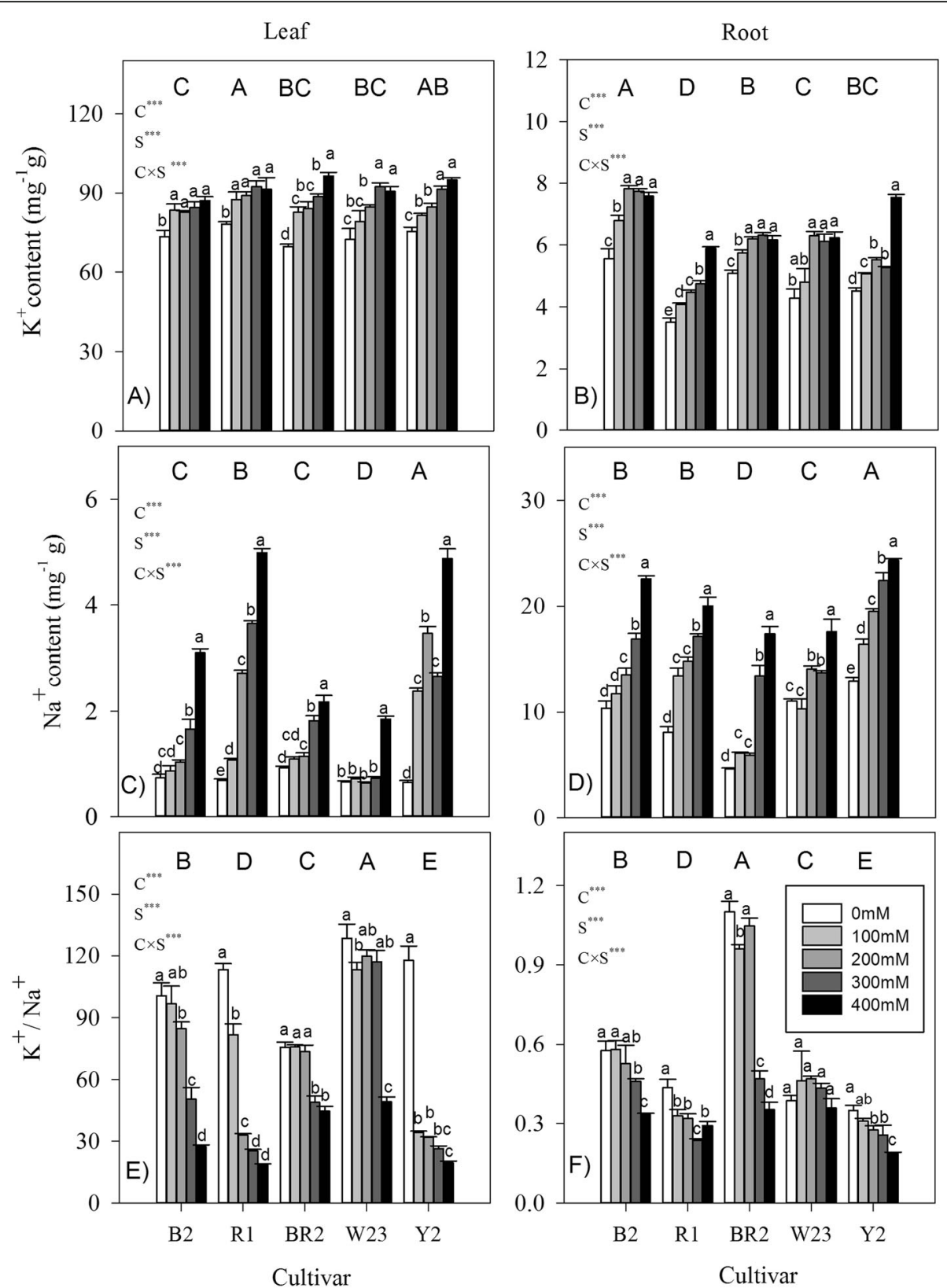

Fig. $6 \mathrm{~K}^{+}$and $\mathrm{Na}^{+}$contents and $\mathrm{K}^{+} / \mathrm{Na}^{+}$ratios in leaves and roots of seedlings of five quinoa cultivars under different saline levels. Different small and capital letters indicate significant differences between the saline levels (S) within each cultivar and between cultivars (C) across different saline levels, respectively, at $P<0.05$ level. Each value is the mean \pm SD of three to four replicate measurements. ${ }^{* * *} P<0.001$

respectively, but was positively correlated with total $\mathrm{Chl}$ contents (Fig. 7). For inorganic ions, except for root $\mathrm{K}^{+}$, salinity tolerance was significant negatively correlated with $\mathrm{K}^{+}$and $\mathrm{Na}^{+}$contents but positively correlated with $\mathrm{K}^{+} / \mathrm{Na}^{+}$ratio in leaves or roots (Fig. 8). Among the traits assessed, $\mathrm{Na}^{+}$contents in leaves and roots had the strongest determinant of salinity tolerance $\left(R^{2}=0.666-0.706\right)$. Relatively, the correlations with leaf organic solutes (proline, protein, or sugar) and salinity tolerance were much lower $\left(R^{2}=0.251-0.341\right)$.

\section{Discussion}

Salt tolerance at seed germination is not consistent with that in the seedling stage

Seed germination often occurs on soil surface in saline environment, exposing the seeds and seedlings to higher salt levels than older plants. Some halophytes are even relatively more sensitive to salinity during the establishment stage [24, 25]. In our study, seed germination of five highland quinoa cultivars did not reduce at low salinity level $(100 \mathrm{mM} \mathrm{NaCl})$, but two of them showed 


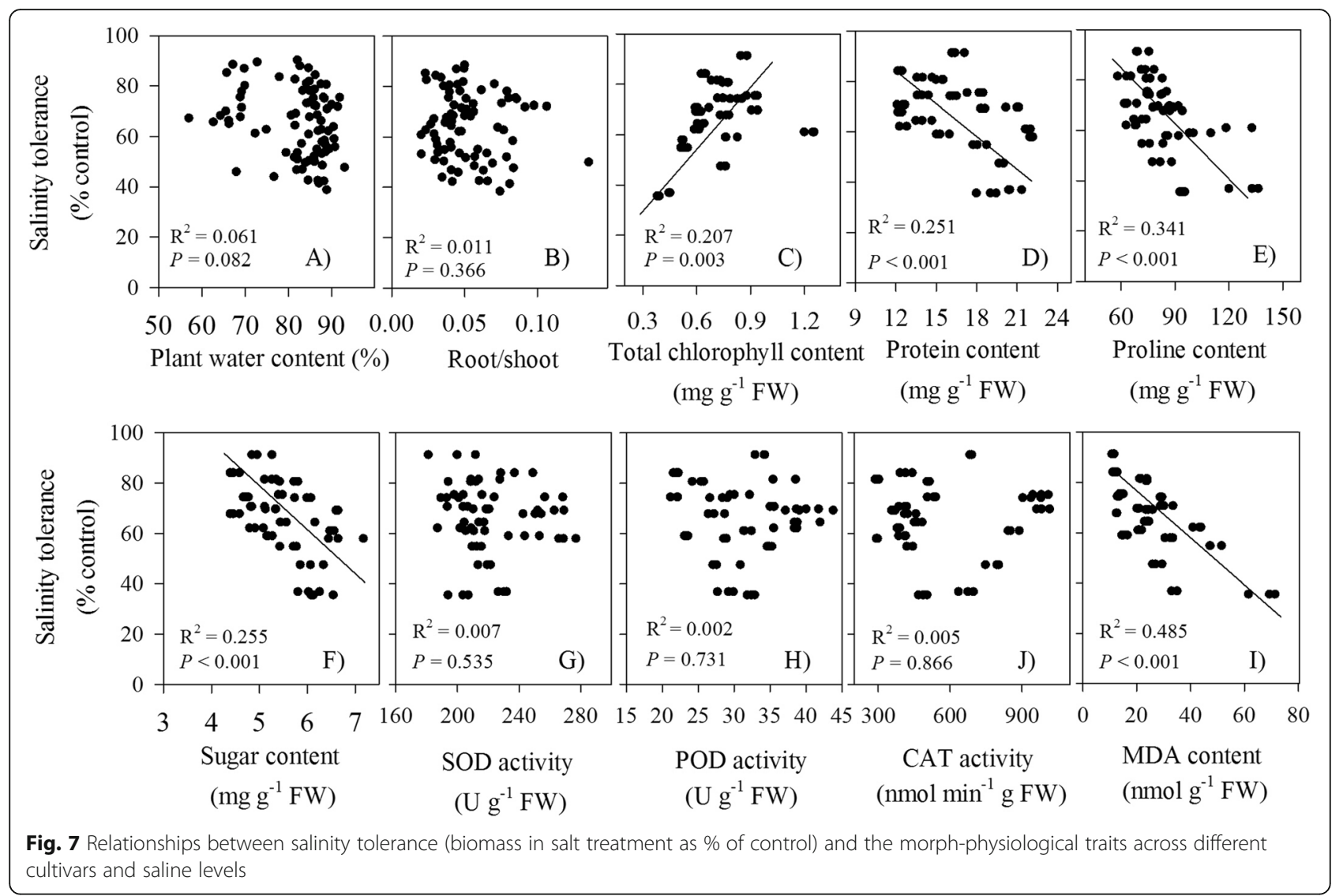

significant decrease at high salinity level $(400 \mathrm{mM} \mathrm{NaCl})$ (Fig. 1). In a previous study with four lowland quinoa genotypes in Chile, only one (BO78) revealed significant reduction in seed germination rate at high salinity level $(300 \mathrm{mM} \mathrm{NaCl})$ [13]; while for a less salt-tolerant cultivar selected in Denmark (cv. 5206), inhibitory effect was obvious only at high salinity levels $(>400 \mathrm{mM} \mathrm{NaCl})$ [12]. Across our studied highland cultivars, tolerance at high salinity level during germination was not consistent with relative plant growth (biomass) reduction. Taken together, it can be said that, at germination, salt tolerance of quinoa largely depends on its genotype and/or ecotype. Since these two processes are governed by different mechanisms [26, 27]; salt tolerance between seed germination and seedling is not necessarily correlated.

\section{Small plants are more tolerant to salt}

Plant water content or leaf water content, though widely employed, is not a strong indicator of turgor in saltstressed plants undergoing osmotic adjustment. This is due to the fact that, greater solute content of cells at higher salinity largely results from ion (e.g. $\mathrm{Na}^{+}$and $\mathrm{Cl}^{-}$) and organic solutes accumulation but not from water loss, especially in halophytes $[1,2]$. In response to the increased salinity levels, plant water content did not vary greatly, but plant height, leaf area, and root length decreased sharply (Fig. 2a-f) (c.f [26].). Compared with the control (i.e. no salinity), plant height of some Peruvian quinoa accessions reduced under salinity, whereas some of them even indicated taller growth [25]. Rather than developing deep and dense root system to ameliorate the negative effects of drought to "find" more water [26], highland quinoa decreased root growth and elongation (Fig. 2c,f), thus, avoiding excessive uptake of $\mathrm{Na}^{+}$ and $\mathrm{Cl}^{-}$and also preventing an escalation in salt concentration in soils [2]. Increase, decrease and maintenance of root/shoot ratio were previously found to be a genotype-dependent response in quinoa [13]. Decreased root/shoot ratio with increasing salinity levels (Fig. 2e) indicated stronger influence of salt on root biomass than shoot biomass $[24,26]$. But the plant's early morphological response via adjustment of root and shoot biomass did not play an important role in salt stress because of absence of any close relationship between root/shoot ratio and salt tolerance (Fig. 7b). Reduction in leaf area (Fig. 2d), the most obvious avoidance mechanism to cope up with salt stress for many crops including halophytes $[2,26]$, resulted in a consequent functional reduction in assimilatory unit of plants and decreased water use by the plant, thus conserving soil moisture.

We did not find significant change in plant biomass between the control and the lowest salinity level (100 


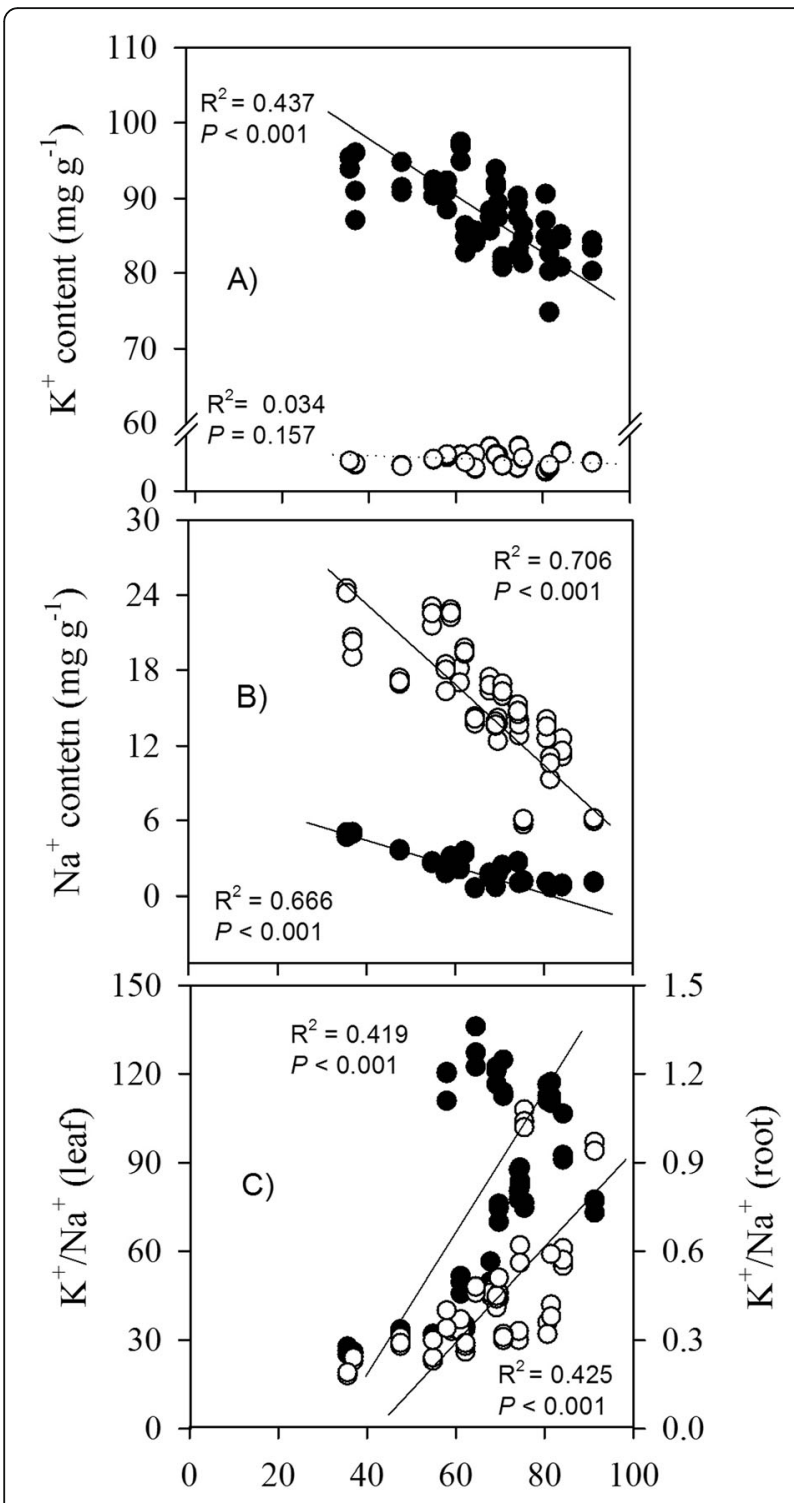

Salinity tolerance $(\%$ control)

Fig. 8 Relationships between salinity tolerance (biomass in salt treatment as \% of control) and ion contents and $\mathrm{K}^{+} / \mathrm{Na}^{+}$ratio in leaves $(\bullet)$ or roots ( $(0)$ across different cultivars and saline levels

$\mathrm{mM} \mathrm{NaCl}$ ) in each studied cultivar, although salinity stress progressively reduced shoot, root, and total biomass (Fig. 2e, f, h). This contrasted with previous results where, in some quinoa genotypes, optimal growth was achieved at intermediate salinity levels (i.e. $100-200 \mathrm{mM}$ ) $[10,12,27]$. Slower growth at initial stage under stress conditions might be an adaptive response of plants to survive that allows them to store resources, repair damaged structures, and restart physiological functions $[15,16]$. A negative trend between plant biomass and salt tolerance within each salt level (Fig. 3) indicated that quinoa cultivars with smaller size (biomass) are more salt tolerant, especially with strong relationship existing at lower salinity levels $(<300$ $\mathrm{mM} \mathrm{NaCl}$ ). Compared with the high salt levels, genetic variation in $\mathrm{Na}^{+}$exclusion may contribute to greater tolerance at moderate salinity conditions where leaf $\mathrm{Na}^{+}$content is below toxic level. Thus, our results provided some support for the presumed tradeoff between seedling's growth potential and salt tolerance at the intraspecific level of highland quinoa, as stress adaptation is costly. This "trade-off" was previously observed in 2 quinoa cultivars having highly contrasting origin with respect to salinity: the salt-tolerant cultivar Utusaya belonging to Salares ecotype, and, the less salt-tolerant Danish-bred cultivar Titicaca [25]. Even in adult plants, a trade-off between salt-stress adaptation and plant growth was found among two coast-lowland quinoa landraces (VI-1, Villarrica) and a salt-tolerant Salares cultivar (R49) [3]. However, in response to drought, the relationship between plant's growth potential and drought tolerance across eight desert grasses may be somehow explained by differential response of plants on soil water content, rather than the inter-specific differences in drought tolerance [20].

Chlorophyll content generally increased in the most salt-tolerant quinoa cultivar (i.e. B2), but decreased in others (Fig. 5f). It was also reported that chlorophyll content significantly decreased in a less salt-tolerant cultivar (Titicaca) but increased in a salt-tolerant cultivar (Utusaya) [26]. Positive relationship between chlorophyll content and salt tolerance (Fig. 7c) may be considered as a compensatory mechanism aimed to protect quinoa for their inability to efficiently exclude $\mathrm{Na}^{+}$from uptake into leaves and enhance $\mathrm{CO}_{2}$ fixation, with less growth penalty.

\section{The measured antioxidant enzymes may not be a key element for salt tolerance}

Increased activities of antioxidant enzymes (like SOD, CAT, POD) might mitigate effects of oxidative damage that often characterize plant responses to stress [28]. SOD dismutates $\mathrm{O}_{2}{ }^{--}$into $\mathrm{H}_{2} \mathrm{O}_{2}$; whereas, presenting in the peroxisomes, CAT mainly catalyzes decomposition of $\mathrm{H}_{2} \mathrm{O}_{2}$ into water and oxygen, and POD mainly scavenge $\mathrm{H}_{2} \mathrm{O}_{2}$ in chloroplasts. As one of the first line of defense against oxidative stress, SOD activity had no positive or negative correlation with salinity tolerance in glycophytes $[29,30]$. But halophytes may show an exceptional ability to utilize the immediate stress-induced SOD production, thus sending stress signals through $\mathrm{H}_{2} \mathrm{O}_{2}$ formation to protect themselves from adverse conditions $[31,32]$. It was found that, the enhanced antioxidant enzyme activities in quinoa cultivar Titicaca could be one of the factors responsible for salt tolerance, although having lower activity than its counterpart in cultivar Utusaya [24, 33]. Previously, a controversial increase and decrease in CAT and POD activity under salt and drought stress in Pichaman genotype of quinoa was 
found; that might be attributed to both genetic variation and variances in kinetics of stress development [25]. At the lowest salt level, antioxidant enzymes counteracted the adverse effects of $\mathrm{O}_{2}{ }^{-}$as well as $\mathrm{H}_{2} \mathrm{O}_{2}$, since the activities of antioxidant enzymes (SOD, POD and CAT) increased but MDA did not accumulate greatly in leaves (Fig. 4). Consequently, a degree of oxidative damage at cellular level was mitigated. Antioxidant system works in a coordinated manner, SOD activity producing cytotoxic $\mathrm{H}_{2} \mathrm{O}_{2}$, while itself being neutralized by superoxide [28]. Whereas at higher salt levels (>100 mM NaCl), SOD activities continued to increase; POD and CAT activities first increased and then decreased, and, MDA also accumulated significantly (Fig. 4). Significant increase in leaf MDA content at higher salt levels in all cultivars can be evidence of increased damage to membranes due to generation of more reactive oxygen species (ROS). The plausible answer in our study might be the important role played by $\mathrm{H}_{2} \mathrm{O}_{2}$ as a second messenger, triggering cascades of adaptive responses at both physiological and genetic levels, where rapid conversion of $\mathrm{O}_{2}{ }^{-}$to $\mathrm{H}_{2} \mathrm{O}_{2}$ by $\mathrm{SOD}$ is essential for generating early defense signal in halophytes [2, 31]. Having enough SOD 'in stock', quinoa plants rapidly induce $\mathrm{H}_{2} \mathrm{O}_{2}$ levels, rather than detoxifying by SOD, which give them a certain adaptive advantage. Compared with Arabidopsis thaliana (a glycophyte), it was clear that Cakile maritime (a halophyte) could quickly send stress signals through $\mathrm{H}_{2} \mathrm{O}_{2}$ and had an efficient antioxidant mechanism to scavenge it upon completion of signaling [34]. It was also reported that high salt-induced reduction of CAT activity might be explained by the requirement to increase $\mathrm{H}_{2} \mathrm{O}_{2}$ levels to be used in stress signal transduction [28]. In addition, $\mathrm{H}_{2} \mathrm{O}_{2}$ played an important role in the regulation of $\mathrm{K}^{+} / \mathrm{Na}^{+}$ homeostasis and increased resistance to salt stress in callus tissue of salt-tolerant Populus euphratica [35]. Thus, it will be interesting to evaluate the actual role (signaling or scavenging) of CAT and POD in halophytes like quinoa.

Salinity tolerance was not closely related to antioxidant enzyme activities (SOD, POD, or CAT) across different salt levels and quinoa cultivars (Fig. 7g-j), similar to the genotypes of barley [29] and some halophytes (e.g. Atriplex lentiformis) [32]. The antioxidant enzymes, therefore, may not be a key element for salt tolerance in highland quinoa. As a halophyte, quinoa possesses efficient means to handle salt load (e.g. $\mathrm{Na}^{+}$exclusion from the cytosol) without the requirement of a high level of antioxidant activity, as they simply prevent excessive ROS formation in salt stress conditions [10, 32]. Genetic differences in salinity tolerance are not necessarily owe to differences in the ability to detoxify ROS. Additionally, although halophytes may use the antioxidant machinery more efficiently than glycophytes, non-enzymatic antioxidants, e.g., glutathione reductase and glutathione, and compatible solutes (mannitol, myo-inositol, proline and glycine-betaine, etc.) present in quinoa can play a crucial role $[3,27]$.

\section{Accumulation of organic osmolytes may be adaptive}

The contents of organic solutes in leaves (i.e. soluble sugar, protein and proline) generally increased with increasing salt levels for each studied cultivar (Fig. 5a-c), which was also widely reported in some quinoa genotypes in response to drought and salt stress [23, 36]. Accumulation of soluble sugars and other compatible solutes (e.g. proline) not only allow plants to decrease osmotic potential and maintain the cellular turgidity necessary for cell expansion under salinity stress conditions (osmotic adjustment) but also act as osmoprotectants, helping the cells to protect and maintain membrane integrity $[4,30]$. The enhanced production of total soluble sugars in quinoa seedlings was presumed to adjust osmotically to saline environment [27]. As an osmolyte that is frequently found in plants subjected to drought and salinity conditions [32, 37], the increased sugar content in quinoa might be due to salinity stress, which was further supported by high activities of soluble acid invertase and sucrose-phosphate synthase in salt-stressed quinoa seedlings [13]. Excessive high content of sugar may, however, inhibit photosynthesis by a feedback mechanism, causing a reduction of leaf development and hence plant growth; similar to the negative correlation observed here between sugar contents and salt tolerance (Fig. 7f). Carbohydrates act as an active carbon sink prior to plant growth; an increase in carbon storage and decrease in plant growth could be a plastic or evolutionary response to carbon-limiting conditions [16, 37].

Apart from osmotic adjustment, proline is considered to perform multiple antioxidant functions, thereby ensuring membrane stabilization, and protection of photosynthetic machinery against oxidative stress in developing leaves [1]. However, there were inconsistent results about whether proline accumulation serves as a mechanism to tolerate salinity or it was a negative consequence of salinity [38, 39]. For instance, in rice, some authors suggested that salt-stress induced proline accumulation was related to the degree of salt tolerance [40]. Whereas others argued that proline accumulation in salt-sensitive rice was a symptom of salt stress injury reflecting poor performance and greater damage, resulting from the increased ornithine $\delta$-aminotransferase activity and the endogenous pool of its precursor glutamate [39]. Proline enhancement occurred at the onset of the lower salinity level in quinoa (Fig. 5c), supporting the hypothesis that this accumulation is initially a reaction to salt stress damage $[4,38]$. However, the relationship between the ability of proline accumulation on stress imposition and specie's stress tolerance 
is not very clear, although plant species differed greatly in the amount of proline responded to stress. For instance, cell elongation in roots in drought-stressed maize was maintained in cells that accumulate proline; hence, proline accumulation was not associated with reduced growth [41]. The inverse relationship between proline content and salt tolerance in highland quinoas (Fig. 7e) may be related to the fact that the synthesis of proline consumed high nitrogen source and energy, at the cost of plant growth. This result in our studied highland quinoas contrasted partly with that in four lowland quinoa genotypes, where the most salt tolerant genotype showed the highest increment in proline content upon salt conditions [13], but consistent with salt-sensitive barley [4] and sorghum [38]. Even at the cellular and, ultimately, organismal level, it is clear that the level of proline accumulation and the amount of growth are inversely correlated under salt conditions; being a part of adaptation process, proline may act as a signaling molecule capable of activating multiple responses [42]. Being demonstrated in a range of halophytic species, the beneficial effect of adaptive proline accumulation is that it served as an osmolyte and protection for quinoa plants under salt-stress conditions, rather than enhancing plant growth (salt tolerance) [4]. Whereas, more work are needed to understand the relationship between proline accumulation, stress adaptation, and control of plant growth and development in quinoa, especially in the field.

\section{$\mathrm{K}^{+} / \mathrm{Na}^{+}$ratio is positively correlated to salt tolerance}

Leaves had much lower $\mathrm{Na}^{+}$content, but higher $\mathrm{K}^{+}$content than roots (Fig. 6a-d). As a whole-body response in adaptation to salt, plants preserve $\mathrm{Na}^{+}$in the roots, due to their relatively higher tolerance to ion toxicity than leaves, and restrict $\mathrm{Na}^{+}$flux to the shoot and leaves. Compared with roots, much lower leaf $\mathrm{Na}^{+}$content suggested that these quinoa cultivars are " $\mathrm{Na}^{+}$excluders" [14]. $\mathrm{Na}^{+}$exclusion from cells and compartmentalization and safe lock of excessive $\mathrm{Na}^{+}$in the vacuole of leaves in quinoa are important protective ways in response to salt-induced ion toxicity at the cellular level [43]. Moreover, quinoa plants tolerate saline conditions by dumping excess salt into specialised epidermal bladder cells on the leaves, which constitutively sequester and excrete them actively from metabolically active cells $[10,43]$. It is now becoming clear that the inward-rectifier highaffinity $\mathrm{K}^{+}$transporters (HKT1.2) is the underlying oneway accumulation system playing a key role for $\mathrm{Na}^{+}$load into bladder cells in quinoa [11]. This surplus salt, mainly $\mathrm{Na}^{+}$, compartmentalize from the leaf blades into the bladder hairs located on the leaf surfaces, from where it can be washed off by rain.

Salt increased $\mathrm{K}^{+}$and $\mathrm{Na}^{+}$contents in both leaves and root (Fig. 6a-d); the accumulated inorganic ions in tissues thereby enable quinoa plants to maintain cell turgor and to reduce transpiration under salt stressed conditions, via adjustment of water potential $[2,12]$. Potassium is released from roots to xylem for transport to the leaves; increased leaf $\mathrm{K}^{+}$content could be attributed to an exchange between $\mathrm{Na}^{+}$and $\mathrm{K}^{+}$in the proximal part of roots [44]. Our results are consistent with the previous works that accumulation of inorganic ion and organic solutes occurred in saltstressed quinoa plants [5, 12, 25], although inorganic osmoregulation had the strongest contribution to osmotic adjustment (ca. 90\%) [12]. Higher $\mathrm{K}^{+}$content with increasing salinity levels indicated that $\mathrm{K}^{+}$uptake was enhanced by $\mathrm{Na}^{+}$supply. This seems to be counterintuitive, as the two ions competing for major binding sites in the important metabolic processes in cytoplasm and $\mathrm{K}$ deficiency always occurred when imposed by salinity [1]. In other work on barley [45] and some halophytes, e.g. quinoa [5, 10, 12], $\mathrm{K}^{+}$accumulated in some tissues and contributed more efficiently in osmotic adjustment in cells of leaves under high salinity conditions. In the former work, it was interpreted that a higher demand is for "free" $\mathrm{K}^{+}$, not "structural" $\mathrm{K}^{+}$, in order to osmotically adjust and support leaf expansion. We only measured total ion content but not fluxes themselves, therefore, it is not possible to confirm such possibilities from our study. Essential for a range of physiological processes in response to salt stress, leaf $\mathrm{K}^{+}$loss may activate an amount of caspase-like proteases triggering programmed cell death, and thus enhance leaf senescence [46]. In this context, the quinoa plants' ability to increase $\mathrm{K}^{+}$uptake and retention in plant tissues (especially in leaf) is a part of its extraordinary salinity tolerance (c.f [10].).

Salinity tolerance was significantly negatively correlated with $\mathrm{K}^{+}$and $\mathrm{Na}^{+}$contents in leaves or roots, except for root $\mathrm{K}^{+}$(Fig. 8a,b). Compared with the organic osmolytes (i.e. protein, sugars, and proline) in leaves, inorganic ions showed higher correlations with salinity tolerance (Figs. 7, 8), indicating that they probably made larger contribution in osmoregulation. Relative to organic osmolytes with high energy cost of de novo synthesis [47], it is much more advantageous and metabolically cheaper for plants to use inorganic solutes for osmotic adjustment, assuming it will not interfere with cell metabolism. But strikingly, in 11 genotypes of " $\mathrm{Na}^{+}$includer", a positive correlation was observed between the accumulated $\mathrm{Na}^{+}$amount and plant's salinity tolerance [14]. An inverse relationship between leaf $\mathrm{Na}^{+}$accumulation and salinity tolerance often occurred when different genotypes within a species are compared, but this is not the case in inter-specific comparison, such as in wheat and barley [1]. On the other hand, the general assumption of increased levels of $\mathrm{K}^{+}$to mitigate salt stress is probably oversimplified. In $\mathrm{NaCl}$ treated Arabidopsis plants, over-accumulation of $\mathrm{Na}^{+}$ and $\mathrm{K}^{+}$triggered growth reduction, through stomatal regulation or systemic stress responses, rather than 
$\mathrm{Na}^{+}$toxicity and water deficit [2]. The negative correlation between leaf $\mathrm{Na}^{+}$content and plant salinity tolerance suggested that the major mechanism contributing to salinity tolerance was to exclude salt from their leaves, rather than vacuolar $\mathrm{Na}^{+}$sequestration. At the whole-plant level, protecting young leaves from excessive $\mathrm{Na}^{+}$amounts has long been considered as a key attribute of $\mathrm{Na}^{+}$compartmentalization in many species $[1,43]$. Quinoa is no exception.

In addition, maintenance of ion (especially $\mathrm{K}^{+}$) homeostasis is essential for ionic and $\mathrm{pH}$ homeostasis, enzyme activities, and cytosolic $\mathrm{K}^{+}$attributed to the plant adaptive responses to a broad range of abiotic stresses [1, 44]. Quinoa plants accumulated more $\mathrm{Na}^{+}$than $\mathrm{K}^{+}$under salinity stress, as the $\mathrm{K}^{+} / \mathrm{Na}^{+}$ratios in both leaves and roots decreased with increasing salinity levels (Fig. 6e,f). Being one of the most important cations for plant growth, $\mathrm{K}^{+}$is required as an enzyme cofactor and as a vacuolar osmoticum. The catalytic sites normally bind the essential $\mathrm{K}^{+}$and maintain a high cytosolic $\mathrm{K}^{+} / \mathrm{Na}^{+}$ ratio to enhance salt tolerance [44]. Similarities between $\mathrm{Na}^{+}$and $\mathrm{K}^{+}$lead to competition during transport in these sites. The $\mathrm{K}^{+} / \mathrm{Na}^{+}$ratio in leaves or roots was positively correlated with salinity tolerance (Fig. 8c), which was also found in drought resistant quinoa [36] and, commonly, in glycophytes [1]. Thus, maintenance of ion homeostasis is critical for salt tolerance of our studied highland quinoa plants. As an index of salinity tolerance, $\mathrm{K}^{+} / \mathrm{Na}^{+}$ratio in the vegetative tissues (i.e. leaf or root), therefore, can be used as a convenient selection criterion in the breeding of highland quinoa cultivars.

\section{Conclusions}

Quinoa cultivars belonging to highland ecotype revealed substantial variations in plant size (biomass) and salinity tolerance, where salinity tolerance of quinoa was negatively correlated with plant size. The interactions of cultivar and salt were found for all measured plant traits, except for shoot/root ratio. With increasing salt levels, accumulation of organic (protein, sugars, and proline) and inorganic $\left(\mathrm{K}^{+}\right.$,
$\mathrm{Na}^{+}$) substances in quinoa plants might be a reflection of the energetic cost associated with osmotic adjustment. During resource limitation under salt stress conditions, active synthesis of these compounds may enable plants to survive and recover from stress, at the expense of plant growth as those solutes are no longer available for cell wall and protein synthesis $[1,3,37]$. Leaf osmoregulation, $\mathrm{K}^{+}$retention, $\mathrm{Na}^{+}$exclusion, and ion homeostasis are the main physiological mechanisms, rather than leaf antioxidant regulations, conferring salinity tolerance to these cultivars. The C-S-R theory is applicable to highland quinoa cultivars, since an apparent trade-off between growth and salt tolerance existed. This trade-off creates a practical challenge to instill resilience into domesticated populations without compromising yields, although plant breeders generally wish to identify the fast-growing and stress-tolerant genotypes.

\section{Methods}

Plant materials and experimental design

Seeds of 5 cultivars of $C$. quinoa, all belonging to the highlands ecotype, were obtained from the quinoa gene bank of Universidad Nacional del Altiplano, Peru. Brief information of the studied cultivars has been described in Table 1. Mature seeds were sown on dishes $(15 \mathrm{~cm})$ containing autoclaved half-strength MS medium and $0.6 \%(\mathrm{w} / \mathrm{v})$ Phytagel (Sigma-Aldrich). Plates (5 per treatment) contain 40 seeds each in growth chambers at $25 \pm 0.5^{\circ} \mathrm{C}$ under a $14 / 10 \mathrm{~h}$ light/dark photoperiod $\left(150 \mu \mathrm{mol} \mathrm{m} \mathrm{s}^{-1}\right)$. To determine seed germination in response to salt, seeds were sown on media containing 0 (control), 100 and $400 \mathrm{mM} \mathrm{NaCl}$. As the fact that quinoa's seeds germinated unusually fast [23], percentage germination was measured on the 5th day after sowing.

For seedling growth, the experiment was carried out in a glass greenhouse at a temperature between $19^{\circ} \mathrm{C}$ and $25^{\circ} \mathrm{C}$ and an average humidity of ca. $75 \%$ in Xishuangbanna Tropical Botanical Garden $\left(21^{\circ} 56^{\prime} \mathrm{N}, 101^{\circ} 15^{\prime} \mathrm{E}\right)$, Chinese Academy of Sciences. The quinoa plants were grown in 5 - $\mathrm{L}$ plastic pots containing $2.0 \mathrm{~kg}$ of a mixture (v/v) of $80 \%$ Novarbo Substrates (Novarbo Oy, Finland)

Table 1 Origin and characters of the quinoa cultivars used in this experiment

\begin{tabular}{|c|c|c|c|c|}
\hline Genotype & Local code & Origin & Photoperiod sensitivity & Other characters \\
\hline$\# 23$ & B2 & Peru (Puno) & Neutral day & $\begin{array}{l}\text { White stem and inflorescence, green leaves, less tolerant to frost. } \\
\text { Late maturing. Black seeds; seed weight: } 0.00297 \mathrm{~g} \text { per seed. }\end{array}$ \\
\hline \# 4 & $\mathrm{R} 1$ & Peru (Puno) & Short-neutral day & $\begin{array}{l}\text { Red stem and inflorescence, red young leaves, tolerant to frost } \\
\text { and downy mildew. Early maturing. Red seeds; seed weight: } \\
0.00272 \mathrm{~g} \text { per seed. }\end{array}$ \\
\hline \# 24 & BR2 & Peru (Puno) & Short day & $\begin{array}{l}\text { White stem. Maturing medium-early to late. Brown seeds; seed } \\
\text { weight: } 0.00349 \mathrm{~g} \text { per seed. }\end{array}$ \\
\hline \# 32 & W23 & Peru (Casco) & Short day & $\begin{array}{l}\text { White stem and inflorescence; tolerant to frost and drought. } \\
\text { Early maturing. White seeds; seed weight: } 0.00292 \mathrm{~g} \text { per seed. }\end{array}$ \\
\hline$\# 14$ & $Y 2$ & Bolivia (southern altiplano) & Short day & $\begin{array}{l}\text { Yellow stem. Panicle colored from white to yellow. Late maturing. } \\
\text { Yellow seeds; seed weight: } 0.00486 \mathrm{~g} \text { per seed. }\end{array}$ \\
\hline
\end{tabular}


and $20 \%$ sandy soil. Five to six surface sterilised seeds per pot were sown. When seedlings reached the two-leaf stage, plants were thinned to two with uniform growth per pot. Plants were randomly rearranged twice a week throughout the experimental period, to ensure uniform growth conditions. When plants had four to five wellexpanded leaves, they were watered with Hoagland's solution 2 times per week, maintaining at field capacity until the beginning of the stress treatment. Afterwards, plants of each cultivar were divided into 5 groups: plants were watered every 2 days with $200 \mathrm{~mL}$ Hoagland's solution supplemented with 5 different $\mathrm{NaCl}$ contents [i.e., 0 (control), 100, 200, 300, and $400 \mathrm{mM}$ ]. Salt stress treatment was imposed for 21 days; 8 replicates (pots) were used for each treatment within each cultivar.

\section{Morphology, growth and chlorophyll parameters}

At the end of the experiment, seedlings were harvested and the whole-plant fresh weight (FW) was immediately assessed. Subsequently, plant height and root length were measured. All leaf samples per individual plant were measured with a LI-3000C leaf area meter (LI-Cor Inc., Lincoln, NE, USA). After that, plant samples were dried at $70^{\circ} \mathrm{C}$ for $48 \mathrm{~h}$ to constant weight to obtain plant biomass (dry weight, DW) per individual plant; and dry weights of leaves, stems, and roots were separately determined. Plant water content (\%) was calculated as: (FW$\mathrm{DW}) / \mathrm{FW} \times 100$ at individual plant level. For leaf physiological and biochemical measurements, the fullyexpanded, young leaves were used. Leaf chlorophylls (Chl) were extracted in $80 \%$ acetone and absorbance at 663 and $645 \mathrm{~nm}$ were measured. $\mathrm{Chl} \mathrm{a}, \mathrm{Chl} \mathrm{b}$ and total $\mathrm{Chl}$ contents were then calculated. Morphological and growth measurements were made on 5-7 plants, while physiological and biochemical measurements were made on one leaf per plant from 3 to 4 plants per cultivar per treatment.

\section{Measurements of antioxidant enzyme activities and lipid peroxidation}

For antioxidant enzyme extractions, $0.5 \mathrm{~g}$ of fresh leaves was homogenized with $50-\mathrm{mM}$ potassium phosphate buffer (pH 7.8), containing $1 \mathrm{mM}$ EDTA, $3 \mathrm{mM} 2-$ mercaptoethanol, and $2 \%(\mathrm{w} / \mathrm{v})$ polyvinyl-poly-pyrrolidone. The filtered homogenate was then centrifuged at $15,000 \mathrm{~g}$ for $30 \mathrm{~min}$ at $4{ }^{\circ} \mathrm{C}$, and the resulting supernatant was used to evaluate the activity of superoxide dismutase (SOD, EC 1.15.1.1), catalase (CAT, EC 1.11.1.6), and peroxidase (POD, EC 1.11.1.7). All enzyme activities were measured at $25^{\circ} \mathrm{C}$ by an UV-B spectrophotometer (UV-B 2501, Shimadzu, Japan). SOD activity was assayed by monitoring the inhibition of photochemical reduction of nitro blue tetrazolium (NBT) using the method of Beauchamp and Fridovich (1971) [48]. One unit of SOD activity was defined as the amount of enzyme required to cause $50 \%$ inhibition of NBT reduction. The POD activity was determined as described by Hemeda and Kelin (1990) [49] using guaiacol as a substrate. One unit of POD activity was defined as the amount of enzyme that increased the absorbance at $470 \mathrm{~nm}$ by 0.001 absorbance unit per min. Catalase activity was estimated by monitoring the disappearance of $\mathrm{H}_{2} \mathrm{O}_{2}$ at $240 \mathrm{~nm}$ [50]. Membrane lipid peroxidation was recorded by the spectrophotometric determination of malondialdehyde using thiobarbituric acid.

\section{Determinations of organic and inorganic solutes}

The soluble protein content was measured as described by Bradford (1976) [51]; bovine serum albumin was used as a standard. Total soluble sugar was estimated from the glucose standard curve according to Dubois et al. (1956) [52]. Free proline content was determined according to Bates et al. (1973) [53] with minor modifications. The proline content was determined from a standard curve of L-proline.

For the measurements of $\mathrm{Na}^{+}$and $\mathrm{K}^{+}$contents, dryashed tissues (leaf and root) were wet digested using $\mathrm{HNO}_{3}: \mathrm{HClO}_{4}(7: 3 \mathrm{v} / \mathrm{v})$. The contents of $\mathrm{Na}^{+}$and $\mathrm{K}^{+}$ were determined using an inductively coupled plasma atomic emission spectrometry (iCAP6300, Thermo Fisher Scientific, USA).

\section{Statistical analyses}

Data was analyzed with a two-way ANOVA for each variable, with cultivar $(C)$ and salinity $(S)$ as main fixed factors plus an $\mathrm{C} \times \mathrm{S}$ interaction term, followed by a Tukey HSD post hoc test within cultivars or salinity levels. We tested the assumptions of an ANOVA prior to analyses. Transformation was applied before statistical analysis being performed, when necessary. Pearson's correlations were used to analyzed the correlations amongst traits. All statistical analyses were conducted using SPSS version 21.0 (SPSS, Chicago, IL, USA).

\section{Abbreviations \\ CAT: Catalase; Chl: Chlorophylls; MDA: Malondialdehyde; POD: Peroxidase; SOD: Superoxide dismutase}

\section{Acknowledgements}

We thank Ming Yin for the data collection of seed germination, $\mathrm{Xu}$ Jin and Screetama Bhadra for their comments on the draft.

\section{Authors' contributions}

QG performed experiments. ZC designed and wrote the paper. All authors have read and approved the manuscript.

\section{Funding}

This work was supported by the grants from the National Natural Science Foundation of China $(31670686,31971697)$ and the '135' Program of Chinese Academy of Sciences (2017XTBG-T02) to ZC.

Availability of data and materials

The datasets generated during the current study are available from the first author on reasonable request. 


\section{Ethics approval and consent to participate}

Not applicable.

\section{Consent for publication}

Not applicable.

\section{Competing interests}

The authors declare that they have no competing interests.

Received: 20 October 2019 Accepted: 5 February 2020

Published online: 12 February 2020

\section{References}

1. Munns R, Tester M. Mechanisms of salinity tolerance. Ann Rev Plant Biol. 2008; $59: 651-81$

2. Acosta-Motos JR, Ortuño MF, Bernal-Vicente A, et al. Plant responses to salt stress: adaptive mechanisms. Agronomy. 2017;7:18.

3. Ruiz KB, Aloisi I, Del Duca S, Canelo V, Torrigiani P, Silva H, Biondi S. Salares versus coastal ecotypes of quinoa: salinity responses in Chilean landraces from contrasting habitats. Plant Physiol Biochem. 2016;101:1-13.

4. Chen Z, Cuin TA, Zhou M, Twomey A, Naidu BP, Shabala S. Compatible solute accumulation and stress-mitigating effects in barley genotypes contrasting in their salt tolerance. J Exp Bot. 2007;58:4245-55.

5. Orsini F, Accorsi M, Gianquinto G, et al. Beyond the ionic and osmotic response to salinity in Chenopodium quinoa: functional elements of successful halophytism. Funct Plant Biol. 2011;38:818-31.

6. Bromham L. Macroevolutionary patterns of salt tolerance in angiosperms. Ann Bot. 2015;115:333-41.

7. Graf BL, Rojas-Silva P, Rojo LE, Delatorre-Herrera J, Baldeón ME, Raskin I. Innovations in health value and functional food development of quinoa (Chenopodium quinoa Willd.). Compr Rev Food Sci Food Saf. 2015;14:431-45.

8. Jacobsen SE, Mujica A, Jensen CR. The resistance of quinoa (Chenopodium quinoa Willd.) to adverse abiotic factors. Food Rev Int. 2003;19:99-109.

9. Risi JC, Galwey NW. The Chenopodium grains of the Andes: Inca crops for modern agriculture. Adv Appl Biol. 1984;10:145-216.

10. Adolf $\mathrm{VI}$, Jacobsen SE, Shabala S. Salt tolerance mechanisms in quinoa (Chenopodium quinoa Willd). Environ Exp Bot. 2013;92:43-54.

11. Böhm J, Messerer M, Müller HM, et al. Understanding the molecular basis of salt sequestration in epidermal bladder cells of Chenopodium quinoa. Curr Biol. 2018;28:3075-85.

12. Hariadi $Y$, Marandon $K$, Tian $Y$, Jacobsen SE, Shabala S. Ionic and osmotic relations in quinoa (Chenopodium quinoa Willd.) plants grown at various salinity levels. J Exp Bot. 2011;62:185-93.

13. Ruiz-Carrasco K, Antognoni F, Coulibaly AK, et al. Variation in salinity tolerance of four lowland genotypes of quinoa (Chenopodium quinoa Willd. as assessed by growth, physiological traits, and sodium transporter gene expression. Plant Physiol Biochem. 2011:49:1333-41.

14. Shabala L, Hariadi Y, Jacobsen SE. Genotypic difference in salinity tolerance in quinoa is determined by differential control of xylem Na loading and stomatal density. J Plant Physiol. 2013;170:906-14.

15. Grime JP. Evidence for the existence of three primary strategies in plants and its relevance to ecological and evolutionary theory. Am Nat. 1977;111: 1169-94.

16. Lambers $\mathrm{H}$, Poorter $\mathrm{H}$. Inherent variation in growth rate between higher plants: a search for physiological causes and ecological consequence. Adv Ecol Res. 1992;23:187-261.

17. Walters MB, Reich PB. Are shade tolerance, survival, and growth linked? Low light and nitrogen effects on hardwood seedlings. Ecology. 1996;77:841-53.

18. Sendall KM, Lusk CH, Reich PB. Trade-offs in juvenile growth potential vs. shade tolerance among subtropical rain forest trees on soils of contrasting fertility. Funct Ecol. 2016;30:845-55.

19. Ouedraogo DY, Mortier F, Gourlet-Fleury S, Freycon V, Picard N. Slowgrowing species cope best with drought: evidence from long-term measurements in a tropical semi-deciduous moist forest of Central Africa. J Ecol. 2013:101:1459-70.

20. Fernández RJ, Reynolds JF. Potential growth and drought tolerance of eight desert grasses: lack of a trade-off? Oecologia. 2000;123:90-8.

21. VanWallendael A, Soltani A, Emery NC, Peixoto MM, Olsen J, Lowry DB. A molecular view of plant local adaptation: incorporating stress-response networks. Ann Rev Plant Biol. 2019;70:559-83.
22. Darychuk N, Hawkins BJ, Stoehr M. Trade-offs between growth and cold and drought hardiness in submaritime Douglas-fir. Can J For Res. 2012;42: 1530-41.

23. Maleki P, Bahrami HA, Saadat S, Sharifi F, Dehghany F, Salehi M. Salinity threshold value of quinoa (Chenopodium quinoa Willd.) at various growth stages and the appropriate irrigation method by saline water. Comm Soil Sci Plant Anal. 2018:49:1815-25.

24. Panuccio MR, Jacobsen SE, Akhtar SS, Muscolo A. Effect of saline water on seed germination and early seedling growth of the halophyte quinoa. AoB Plants. 2014;6.

25. Gómez-Pando LR. Álvarez-Castro R, Eguiluz-de la Barra a. effect of salt stress on Peruvian germplasm of Chenopodium quinoa Willd.: a promising crop. J Agron Crop Sci. 2010;196:391-6.

26. Adolf VI, Shabala S, Andersen MN, Razzaghi F, Jacobsen SE. Varietal differences of quinoa's tolerance to saline conditions. Plant Soil. 2012:357: 117-29.

27. Ruffino AMC, Rosa M, Hilal M, Gonzalez JA, Prado FE. The role of cotyledon metabolism in the establishment of quinoa (Chenopodium quinoa) seedlings growing under salinity. Plant Soil. 2010;326:213-24.

28. Mittler R. Oxidative stress, antioxidants and stress tolerance. Trends Plant Sci. 2002;7:405-10.

29. Maksimovic JD, Zhang JY, Zeng FR, Živanovic BD, Shabala L, Zhou MX, Shabala S. Linking oxidative and salinity stress tolerance in barley: can root antioxidant enzyme activity be used as a measure of stress tolerance? Plant Soil. 2013;365:141-55.

30. Sarabi B, Bolandnazar S, Ghaderi N, Ghashghaie J. Genotypic differences in physiological and biochemical responses to salinity stress in melon (Cucumis melo L.) plants: prospects for selection of salt tolerant landraces. Plant Physiol Biochem. 2017;119:294-311.

31. Flowers TJ, Colmer TD. Salinity tolerance in halophytes. New Phytol. 2008; 179:945-63.

32. Bose J, Rodrigo-Moreno A, Shabala S. ROS homeostasis in halophytes in the context of salinity stress tolerance. J Exp Bot. 2014;65:1241-57.

33. Amjad M, Akhtar SS, Yang A, Akhtar J, Jacobsen SE. Antioxidative response of quinoa exposed to iso-osmotic, ionic and non-ionic salt stress. J Agron Crop Sci. 2015:201:452-60

34. Ellouzi H, Hamed KB, Cela J, Munné-Bosch S, Abdelly C. Early effects of salt stress on the physiological and oxidative status of Cakile maritima (halophyte) and Arabidopsis thaliana (glycophyte). Physiol Plant. 2011;142: 128-43.

35. Sun J, Wang MJ, Ding MQ, et al. $\mathrm{H}_{2} \mathrm{O}_{2}$ and cytosolic $\mathrm{Ca}^{2+}$ signals triggered by the PM H-coupled transport system mediate $\mathrm{K}^{+} / \mathrm{Na}^{+}$homeostasis in $\mathrm{NaCl}$-stressed Populus euphratica cells. Plant Cell Environ. 2010;33:943-58.

36. Iqbal $H$, Chen $Y$, Waqas M, Shareef M, Raza ST. Differential response of quinoa genotypes to drought and foliage-applied $\mathrm{H}_{2} \mathrm{O}_{2}$ in relation to oxidative damage, osmotic adjustment and antioxidant capacity. Ecotoxicol Environ Saf. 2018:164:344-54.

37. Geng YJ, Chen L, Yang C, Jiao DY, Zhang YH, Cai ZQ. Dry-season deficit irrigation increases agricultural water use efficiency at the expense of yield and agronomic nutrient use efficiency of Sacha Inchi plants in a tropical humid monsoon area. Ind Crop Prod. 2017:109:570-8.

38. Lacerda CF, Cambraia J, Oliva MA, Ruiz HA, Prisco JT. Solute accumulation and distribution during shoot and leaf development in two sorghum genotypes under salt stress. Environ Exp Bot. 2003;49:107-20.

39. Lutts $\mathrm{S}$, Majerus $\mathrm{V}$, Kinet JM. NaCl effects on proline metabolism in rice (Oryza sativa) seedlings. Physiol Plant. 1999;105:450-8.

40. Igarashi $Y$, Yoshiba $Y$, Sanada $Y$, Yamaguchi-Shinozaki K, Wada K, Shinozaki K. Characterization of the gene for $\Delta 1$-pyrroline-5-carboxylate synthethase and correlation between the expression of the gene and the salt tolerance in Oryza sativa L. Plant Mol Biol. 1997;33:857-65.

41. Voetberg GS, Sharp RE. Growth of the maize primary root at low water potentials: III. Role of increased proline deposition in osmotic adjustment. Plant Physiol. 1991;96:1125-30

42. Maggio A, Miyazaki S, Veronese $P$, et al. Does proline accumulation play an active role in stress-induced growth reduction? Plant J. 2002;31:699-712.

43. Bonales-Alatorre E, Shabala S, Chen ZH, Pottosin I. Reduced tonoplast fastactivating and slow-activating channel activity is essential for conferring salinity tolerance in a facultative halophyte, quinoa. Plant Physiol. 2013;162:940-52.

44. Wu H, Zhang X, Giraldo JP, Shabala S. It is not all about sodium: revealing tissue specificity and signalling roles of potassium in plant responses to salt stress. Plant Soil. 2018;431:1-17. 
45. Shabala S, Shabala S, Cuin TA, et al. Xylem ionic relations and salinity tolerance in barley. Plant J. 2010;61:839-53.

46. Shabala S. Salinity and programmed cell death: unravelling mechanisms for ion specific signaling. J Exp Bot. 2009;60:709-12.

47. Raven JA. Regulation of $\mathrm{pH}$ and generation of osmolarity in vascular plants: a cost-benefit analysis in relation to efficiency of use of energy, nitrogen and water. New Phytol. 1985;101:25-77.

48. Beauchamp C, Fridovich I. Superoxide dismutase: improved assays and an assay applicable to acrylamide gels. Anal Biochem. 1971;44:276-87.

49. Hemeda HM, Kelin BP. Effects of naturally occurring antioxidants on peroxidase activity of vegetable extracts. J Food Sci. 1990;55:184-5.

50. Aebi H. Catalase in vitro. Method Enzymol. 1984;105:121-6.

51. Bradford MM. A rapid and sensitive method for the quantitation of microgram quantities of protein utilizing the principle of protein-dye binding. Anal Biochem. 1976;72:248-54.

52. Dubois M, Gilles KA, Hamilton JK, Rebers PA, Smith F. Colorimetric method for determination of sugar and related substances. Anal Chem. 1956;28:350-6.

53. Bates LS, Waldren RP, Teare ID. Rapid determination of free proline for water-stress studies. Plant Soil. 1973;39:205-7.

\section{Publisher's Note}

Springer Nature remains neutral with regard to jurisdictional claims in published maps and institutional affiliations.

Ready to submit your research? Choose BMC and benefit from:

- fast, convenient online submission

- thorough peer review by experienced researchers in your field

- rapid publication on acceptance

- support for research data, including large and complex data types

- gold Open Access which fosters wider collaboration and increased citations

- maximum visibility for your research: over $100 \mathrm{M}$ website views per year

At $\mathrm{BMC}$, research is always in progress.

Learn more biomedcentral.com/submissions 